\title{
Pengaruh Pemberian Minuman Energi terhadap Kadar Serum Kreatinin Rattus norvegicus
}

\author{
Budi Santo1, Dorta Simamora ${ }^{2 *}$ \\ RS PTPN X JL. Bedadung No 2 jember $^{1}$ \\ Bagian Biomedik Fakultas Kedokteran Universitas Wijaya Kusuma Surabaya² \\ *e-mail: dortasimamora@uwks.ac.id
}

\begin{abstract}
Abstrak
Minuman energi merupakan minuman yang semakin banyak digunakan oleh masyarakat dengan tujuan untuk meningkatkan performa kerja, vitalitas, serta daya konsentrasi. Minuman energi juga diduga dapat mempengaruhi fungsi ginjal. Penelitian kali ini bertujuan untuk mengetahui pengaruh minuman energi berbagai merek terhadap kadar serum kreatinin pada tikus Rattus norvegicus jantan. Penelitian ini merupakan penelitian eksperimental murni menggunakan rancangan Randomized post test only control group design. Penelitian menggunakan tikus Rattus norvegicus jantan sebanyak 25 ekor yang terbagi dalam 5 kelompok. Kelompok kontrol, kelompok P1 = minuman berenergi merek hemaviton, $\mathrm{P} 2$ minuman berenergi merek Redbull, P3 minuman berenergi merek Krating Daeng, dan P4 minuman berenergi merek Pather. Pemberian dosis masing-masing minuman energi sebanyak 2,5 ml/ 200 gram BB/ hari selama 1 bulan. Pengambilan darah langsung dari jantung dilakukan untuk mengukur kadar serum kreatinin Rattus norvegicus, kemudian hasilnya dianalisa menggunakan uji One-Way Anova untuk membandingkan kadar serum kreatinin antar kelompok. Hasil uji One-Way Anova didapatkan sebesar $\operatorname{sig} \alpha=0.000$ yang berarti terdapat pengaruh yang signifikan antara kelompok perlakuan dengan kelompok kontrol. Dapat disimpulkan bahwa pemberian minuman energi selama satu bulan dapat menurunkan kadar serum kreatinin Rattus norvegicus. Hal ini diduga akibat adanya reaksi berbagai zat yang terkandung dalam minuman energi seperti: Taurine, gula, vitamin B, kafein, serta bahan pelengkap lain
\end{abstract}

Kata Kunci: minuman energi, serum kreatinin, fungsi ginjal

\section{The Effect of Energy Drinks on Serum Creatinine Levels of Rattus norvegicus}

\begin{abstract}
The energy drink is a beverage that is increasingly being used by the community with the aim to improve work performance, vitality, and concentration. The energy drink is also suspected to affect kidney function. This study aims to determine whether there is influence of various brands of energy drinks toward to the serum creatinine levels in male rats Rattus norvegicus. This is a study with randomized post test only control group design. The study used male rats Rattus norvegicus as many as 25 animals that were divided into 5 groups. The control group, the group $P 1=$ Hemaviton energy drinks, group P2 Redbull energy drinks, group P3 Krating daeng energy drinks, group P4 pather energy drinks. The energy drinks were given as many as $2.5 \mathrm{ml} / 200 \mathrm{~g}$ weight/day for 1 month. Cardiac blood sampling performed to measure the levels of serum creatinine and then the results were analyzed using One-Way Anova to compare the levels of serum creatinine in each group of this study. Results of One-Way Anova test obtained by sig $\alpha=$
\end{abstract}


0.000 which means there was a significant difference between the treatment group and the control group. It can be concluded that the administration of energy drinks during one month to the Rattus norvegicus would be altered the kidney function. It is caused by various substances contained in energy drinks such as taurine, sugar, vitamin B, caffeine, and other supplementary materials.

Keywords : energy drink, creatinine serum, kidney function

\section{PENDAHULUAN}

Diperkirakan lebih dari 6 miliar botol minuman energi pada tahun 2010 terjual di Amerika dibandingkan dengan 2,3 miliar botol pada tahun 2005. Minuman energi merupakan minuman suplemen yang sering digunakan orang dewasa untuk meningkatkan performa dan vitalitas kerja (Hamilton et al, 2013). Minuman energi yang ada di Indonesia yang sering dijumpai antara lain : Kratingdaeng, Lipovitan, M150, Fit Up, Extra Joss dan Hemaviton adalah merk dari minuman energi. Minuman energi tersedia dalam kemasan botol (150ml), kaleng, serta sachets, juga ada dalam bentuk bubuk yang dapat dicampur dengan air (Wiradji, 2003).

Hampir semua dari pria dewasa dan anak remaja pasti pernah mengkonsumsi minuman suplemen ini. Seiring dengan berjalannya waktu ternyata konsumsi minuman energi ini juga meningkat. (Hamilton et al, 2013). Minuman energi adalah minuman yang mengandung caffeine, taurine, vitamin, suplemen herbal, dan pemanis buatan yang dipasarkan untuk meningkatkan energi, stamina, performa, dan konsentrasi. Selain efek positif dari penggunaan minuman energi ini ternyata juga harus diwaspadai efek samping lainnya. Efek samping tersebut seperti: seizures, diabetes, penyakit jantung, gangguan perilaku dan mood, gangguan ginjal, gangguan pada tulang, serta penyakit degeneratif lainnya (Seifert, 2011).

Gangguan kesehatan yang diasosiasikan dengan minuman energi ini terutama fungsi ginjal. Metode pengukuran fungsi ginjal yang umum digunakan saat ini adalah dengan mengukur GFR menggunakan serum kreatinin meskipun tes ini bukan merupakan tes yang paling akurat untuk mengevaluasi fungsi ginjal. (Goldman dan Schafer, 2012)

Dalam penelitian Khayyat $\mathrm{L}$, et al (2014) melaporkan bahwa asam urat serum dan konsentrasi kreatinin secara signifikan meningkat pada tikus yang diberi minuman energi dan menyebabkan terjadinya gangguan fungsi ginjal. Menurut Mossa $\mathrm{AH}$ \& Abbassy, MA (2012), pemberian minuman energi menyebabkan peningkatan urea, asam urat dan kreatinin melalui penghambatan reseptor adenosin 
A2A menyebabkan terjadinya inflamasi intertisial dan memicu peningkatan pada proteinuria yang pada akhirnya dapat merusak fungsi dan struktur ginjal.

Konsumsi kafein yang berlebihan juga berpengaruh pada fungsi pembuluh darah yang akan berhubungan dengan ginjal, apabila hal ini tidak secepatnya dirubah akan berdampak dengan kerusakan pada fungsi ginjal yang dapat menyebabkan Gagal Ginjal Kronis (Hidayati, 2008). Gagal Ginjal Kronik masih menjadi masalah besar didunia. Selain tidak dapat disembuhkan, biaya perawatan dan pengobatannyapun sangat mahal (Supriyadi et al 2011).

Penelitian seperti ini belum banyak dilakukan, namun sudah terdapat sebuah jurnal yang telah meneliti mengenai konsumsi minuman energi terhadap kreatinin yang ditulis di "Biochemical Effects of Energy Drinks Alone or in Combination with Alcohol in Normal Albino Rats" ditulis (Ugwuja, 2014). Berdasarkan berbagai latar belakang penelitian ini bertujuan untuk mengetahui pengaruh konsumsi minuman berenergi terhadap kadar kreatinin.

\section{BAHAN DAN METODE}

Penelitian ini merupakan penelitian eksperimental dengan rancangan penelitian post test only control group design dengan menggunakan 25 ekor obyek penelitian berupa tikus jantan Rattus norvegicus berusia 8 minggu dengan berat 100-150 gram yang terbagi dalam 5 kelompok secara acak. 5 kelompok tersebut yaitu kelompok kontrol, kelompok P1: minuman energi Hemaviton, kelompok P2: minuman energi Redbull, kelompok P3: minuman energi Krating Daeng, kelompok P4: minuman energi Panther.

Penelitian dilakukan di Laboratorium Hewan Coba Fakultas Kedokteran Universitas Wijaya Kusuma Surabaya. Penelitian telah melalui uji laik etik dengan Sertifikat Keterangan kelaikan etik No.10181/SLE/FK/UWKS/2016. Pemberian dosis minuman energi terhadap P1, P2, P3, dan P4 sebanyak 2,5 ml/200g bb/hari yang dilakukan selama 1 bulan yang sebelumnya telah dilakukan aklimatisasi terlebih dahulu selama 3 hari. Sedangkan kelompok kontrol tidak mendapatkan pemberian minuman energi.

Setelah pemberian minuman energi selama 1 bulan kemudian dilakukan terminasi menggunakan Chloroform sebagai bahan anestesi sebelum dilakukan pembedahan pada dada untuk mendapatkan sampel darah jantung yang kemudian disimpan dalam spuit $3 \mathrm{ml}$. Sampel darah jantung yang didapatkan kemudian dilakukan analisa serum kreatinin di Laboratorium Biokimia Fakultas Kedokteran Universitas Wijaya Kusuma. 
Pengaruh Pemberian Minuman Energi terhadap Kadar Serum Kreatinin Rattus norvegicus

Budi Santo, Dorta Simamora

Analisa serum kreatinin menggunakan alat spektrofotometer dengan metode Jaffe.

\section{ANALISIS DATA}

Data serum kreatinin yang didapatkan kemudian dianalisis menggunakan SPSS versi 20. Data penelitian diuji normalitasnya menggunakan uji normalitas Kolmogorov-Smirnov untuk mengetahui normalitas distribusi data. Apabila didapatkan hasil normal kemudian data dianalisis dengan statistik parametrik menggunakan One-way ANOVA. Uji normalitas data menunjukkan bahwa sebaran data penelitian ini normal $(p>$ $0,05)$.

HASIL

Tabel 1. Hasil uji SPSS kadar serum kreatinin pada tiap kelompok

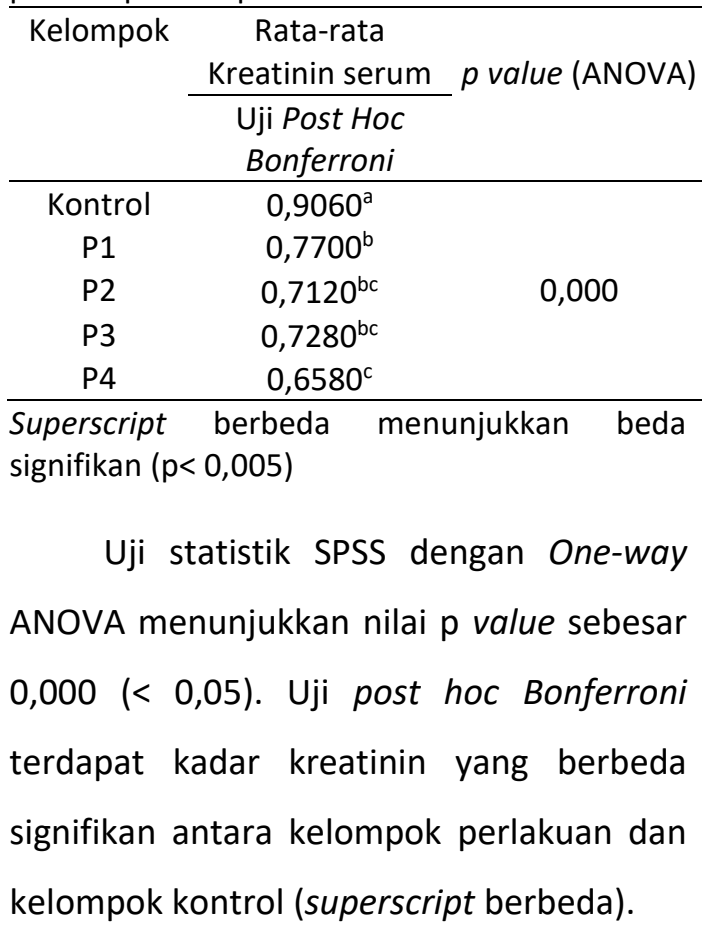

Gambar 1. Nilai rata-rata serum kreatinin tiap kelompok.

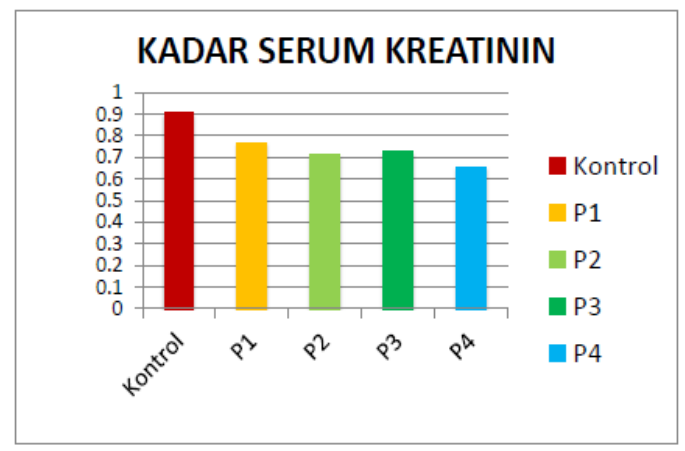

Berdasarkan Gambar 1. dapat terlihat jelas apabila terdapat perbedaan antara kelompok kontrol dengan ke empat kelompok perlakuan (P1 hemaviton, P2 Redbull, P3 Krating Daeng, P4 Pather).

\section{PEMBAHASAN}

Minuman energi mengandung berbagai macam zat yaitu antara lain: caffeine, taurine, vitamin, suplemen herbal, dan pemanis buatan yang dipasarkan untuk meningkatkan energi, stamina, performa, dan konsentrasi (Seifert, 2011).

Hasil penelitian menunjukkan bahwa pemberian minuman energi berbagai merek memberikan pengaruh yang bermakna melalui hasil dari analisis data dengan SPSS. Hal ini terbukti pada uji One-Way Anova menunjukkan nilai signifikansi sebesar $0,000(P$ Value $<0,05)$ yang berarti bahwa terdapat pengaruh pemberian minuman energi terhadap kadar kreatinin pada tiap kelompok. Meskipun terjadi penurunan kreatinin pada kelompok perlakuan jika dibandingkan dengan kontrol, namun kadar kreatinin masih dalam batas yang normal. 
Setelah ditemukan pengaruh pemberian minuman berenergi berbagai merek terhadap kadar kreatinin di semua kelompok, maka peneliti menganalisis pebedaan kadar serum kreatinin pada tiap kelompok menggunakan uji post hoc dengan uji Bonferroni. Hasil uji ini menunjukkan bahwa terdapat perubahan kadar kreatinin yang signifikan antara kelompok kontrol dengan kelompok perlakuan (P1, P2, P3, P4) yang diketahui dari hasil nilai $P$ Value kurang dari 0,05. Pada perbandingan kelompok P1 terhadap kelompok kontrol didapatkan nilai $P$ Value kurang dari 0,05. Kelompok P1 dengan P4 didapatkan $p$ value kurang dari 0,05. Antara kelompok P1 dengan P2, P3 didapatkan nilai $P$ Value lebih besar dari 0,05 . Hal ini menunjukkan bahwa didapatkan perubahan kadar kreatinin yang signifikan antara kelompok P1 dengan kelompok kontrol dan P4, hal sebaliknya yaitu tidak didapatkan pengaruh yang signifikan antara kelompok P1 dengan P2, P3

Pada uji beda antar kelompok P2 dan kelompok kontrol didapatkan hasil $p$ value sebesar 0,000 $(P$ Value $<0,05)$ yang berarti bahwa terdapat perubahan kadar kreatinin yang signifikan antara P2 dan kontrol. Sebaliknya, perbandingan nilai $p$ Value kelompok P2 terhadap kelompok perlakuan lain (P1, P3, P4) didapatkan nilai lebih dari 0,05 yang berarti bahwa tidak didapatkan perbedaan yang signifikan antara kelompok $\mathrm{P} 2$ dengan $\mathrm{P} 1, \mathrm{P} 3, \mathrm{P} 4$.

Hasil $P$ Value sebesar $0,000(p<0,05)$ yang berarti bahwa terdapat perubahan yang signifikan didapatkan pada perbandingan nilai serum kreatinin antara kelompok P3 terhadap kelompok kontrol, sedangkan perbandingan kelompok P3 dengan kelompok P1, P2, P4 relatif tidak didapatkan perubahan yang signifikan. Hal ini ditunjukkan dengan nilai $p$ Value pada perbandingan ke- 4 kelompok tersebut lebih besar dari 0,05.

Pada kelompok P4 yang dibandingkan dengan kelompok kontrol dan P1 didapatkan indikasi bahwa ada pengaruh yang signifikan. Hal ini ditandai dengan nilai $P$ Value sebesar 0,000 terhadap kelompok kontrol dan sebesar 0,02 terhadap kelompok P1. Sedangkan pada perbandigan kelompok P4 dengan kelompok perlakuan lain (P2, P3) tidak didapatkan nilai $P$ Value dibawah 0,05 yang berarti bahwa tidak didapatkan perbedaan yang signifikan antar kelompok tersebut.

Perubahan kadar serum kreatinin berupa penurunan kadarnya pada ke 4 kelompok perlakuan dibandingkan dengan kelompok kontrol ini mungkin dipengaruhi oleh beberapa komposisi yang terdapat pada minuman energi. Peneliti menduga taurine adalah salah satu zat yang dapat mempengaruhi kadar serum kreatinin. 
Pengaruh Pemberian Minuman Energi terhadap Kadar Serum Kreatinin Rattus norvegicus

Budi Santo, Dorta Simamora

Taurine sendiri adalah zat yang terdapat dalam jumlah cukup tinggi pada hewan termasuk juga manusia khususnya pada jaringan saraf, retina dan neutrofil (Aruoma et al, 1988) namun hanya beberapa tumbuhan yang terdapat taurine didalamnya. Taurine mempunyai beberapa fungsi pada tubuh seperti : mempengaruhi eksitabilitas jantung, mempengaruhi pembentukan asam empedu, diduga dapat menyebabkan hipoglikemi, meningkatkan potensi dari insulin, menyebabkan penurunan pada tekanan darah, vasodilatasi, dan menginhibisi impuls saraf (Jacobsen dan Smith, 1968). Red bull juga dapat menurunkan kadar antioksidan serta meningkatkan pembentukan ROS dan stres oksidatif.

Pada hasil penelitian yang kami lakukan terjadi penurunan kreatinin pada tikus yang diberi minuman energi selama satu bulan. Hasil penelitian ini berbeda dengan beberapa penelitian sebelumnya. Menurut Wael Mansy et al (2017) melaporkan bahwa paparan Red bull dengan dosis tinggi selama 12 minggu dapat menyebabkan kerusakan hati dan ginjal. Selain itu red bull juga dapat menurunkan kadar antioksidan serta meningkatkan pembentukan ROS dan stres oksidatif. Hasil yang berbeda ini sangat terkait dengan lamanya pemaparan yang dilakukan. Itulah sebabnya mengkonsumsi minuman energi tidak disarankan pada waktu yang lama.

Toxicodynamic Effects of 'Red Bull' Energy Drink in A

Menurut American Physiological Society (1992) yang menerbitkan jurnal mengenai efek fisiologis Taurine terhadap manusia didapatkan beberapa teori yang dapat mendukung hasil penelitian yaitu Taurine mempunyai sifat osmoregulasi pada tubuh sehinggal hal ini akan menjaga keseimbangan jumlah cairan yang berada didalam pembuluh darah. Hal ini akan berdampak positif terhadap fungsional sel endotel pembuluh darah manusia yang akan lebih terjaga bentuk serta fungsi nya. Dengan fungsi osmoregulasi ini juga Taurine dapat membantu meringankan kinerja ginjal sebagai organ utama yang mengatur keseimbangan cairan dalam tubuh, hal ini mungkin dapat menurunkan kerja ginjal yang di indikasikan dengan penurunan kadar serum kreatinin. Selain Taurine mungkin komposisi lain dalam minuman energi juga berhubungan dengan penurunan kadar serum kreatinin yaitu Vitamin B3, B5, B6, dan juga B12.

Zat natrium atau sodium yang terkandung dalam minuman energi juga diduga peneliti dapat mempengaruhi kadar serum kreatinin. Hal ini terjadi karena efek sodium yang dapat meningkatkan tekanan darah. Pada penelitian yang kami lakukan 
selama 1 bulan, terjadi penurunan kadar kreatinin tidak menunjukkan dampak yang buruk, sebaliknya pada penelitian yang dilakukan, oleh Luma Qasim Ali, (2019) melaporkan hal yang berbeda, yaitu mengkonsumsi minuman energi jangka panjang berpengaruh buruk yang dapat dilihat secara histopatologis dan fisiologis terhadap ginjal dan hati mencit muda yang diberi kafein atau kombinasi kafein dengan taurin atau dengan keracunan gula yang bergantung pada konsentrasi dan jangka waktu konsumsi.

Pada penelitian Sacks et al tahun 2001 didapatkan terjadi penurunan tekanan darah pada kelompok penelitian dengan konsumsi sodium yang paling rendah. Penurunan tekanan darah ini berhubungan dengan penurunan fungsi ginjal sehingga dapat mempengaruhi kadar serum kreatinin. Sama halnya seperti yang dilaporkan oleh Mohamad Riza dan Andina Putri A, (2019), bahwa pemberian minuman energi dan kafein dapat meningkatkan kreatinin dan mempengaruhi fungsi ginjal. Sebaliknya pada penelitian yang kami lakukan ini berbeda, tidak terjadi penurunan kreatinin pada pemaparan minuman energi selama satu bulan.

Selain pengaruh dari komposisi minuman energi, peneliti menduga dosis juga menjadi salah satu hal yang dapat memberikan pengaruh terhadap penurunan kadar serum kreatinin. Pemberian minuman energi pada rentang waktu yang panjang seperti pada penelitian sebelumnya dapat berpengaruh buruk karena dapat meningkatkan kadar asam urat dan kreatinin ini biasanya terkait dan dapat menurunkan fungsi ginjal. Peningkatan kadar urea, asam urat, kreatinin terjadi karena pemberian minuman energi, penghambatan reseptor adenosin A2A selama inflamasi pada interstisial dapat meningkatkan proteinuria akibat rusaknya fungsi dan struktur dari ginjal. Hal ini didukung dengan hasil penelitian mengenai hubungan pemberian minuman energi terhadap kadar serum kreatinin yang pernah dilakukan oleh Ugwuja (2014), didapatkan hasil penurunan kadar serum kreatinin pada kelompok dengan pemberian minuman energi dosis tinggi dibandingkan dengan kelompok yang mendapatkan minuman energi dosis rendah.

Walaupun minuman energi terlihat menguntungkan secara pada kinerja fisik, namun tetap tidak boleh dikonsumsi secara berkepanjangan, karena dapat merugikan kesehatan. Hal ini juga sama seperti yang pernah dilaporkan oleh (Alsunni, 2015).

\section{KESIMPULAN}

Pemberian minuman energi dapat mempengaruhi kadar serum kreatinin pada 
Pengaruh Pemberian Minuman Energi terhadap Kadar Serum Kreatinin Rattus norvegicus

Budi Santo, Dorta Simamora

tikus Rattus norvegicus strain Wistar.

Pemberian minuman energi berbagai merek dengan dosis sebesar $2.5 \mathrm{mg} / 200 \mathrm{~g} \mathrm{BB} /$ hari selama 1 bulan berpengaruh dalam menurunkan kadar serum kreatinin. Terdapat penurunan kadar serum kreatinin pada semua kelompok perlakuan dibandingkan dengan kelompok kontrol $(p<$ $0,05)$.

\section{SARAN}

1. Perlu dilakukan eksplorasi lebih lanjut untuk memastikan zat apa saja selain taurin yang dapat mempengaruhi hasil pada kadar serum kreatinin.

2. Perlu dilakukan penelitian dengan pemberian minuman energi berbagai merek dengan waktu yang lebih lama 3 - 6 bulan untuk melihat berapa besar kerusakan yang terjadi pada ginjal akibat minuman energi.

3. Perlu dilakukan pengembangan penelitian yang ditujukan untuk mengetahui korelasi dosis dengan perubahan kadar serum kreatinin karena pada penelitian ini, peneliti tidak meneliti korelasi dosis minuman energi dengan kadar serum kreatinin.

\section{DAFTAR PUSTAKA}

Alsunni AA, 2015. Energy Drink Consumption: Beneficial and
Adverse Health Effects. Int J Health Sci (Qassim). 9(4): 468-474.

Aruoma O I, Halliwell B, Hoey B, Butler J. 1988. The antioxidant action of taurine, hypotaurine and their metabolic precursors. Biochem J. 256: 251-255.

Goldman L dan Schafer A I, 2012. GoldmanCecil Medicine, $25^{\text {th }}$ Edition, Elsevier Inc, Philadelphia, pp. 833849 chap 130.

Hamilton H A, Boak A, llie G, Mann R E. 2013. Energy Drink Consumption and Associations With Demographic Characteristics, Drug Use and Injury Among Adolescents. Canadian Public Health Association. 104(7): 496500.

Hidayati T, Kushadiwijaya H, Suhardi, 2008. Hubungan Antara Hipertensi, Merokok Dan Minuman Suplemen Energi Dan Kejadian Penyakit Ginjal Kronik. Berita Kedokteran Masyarakat. 24(2): $90-102$.

Huxtable R. J. 1992. Physiological Actions of Taurine. American Physiological Society. 72(1): $101-163$.

Jacobsen J G dan Smith L H. Jr. 1968. Physiological reviews Biochemistry and Physiology of Taurine and Taurine Derivatives. Physiol Rev. 48(2): 485-491. 
Mohamad R dan Andina PA, 2019. The Comparison Effect Of Energy Drinks And Coffee On Creatinin Level In Rats. International Journal of Human and Health Sciences. $3(4)$.

Mossa AH \& Abbassy MA, 2012. Adverse Haematological and Biochemical Effects of Certain Formulated Insecticides in Male Rats. Res J Environ Toxicol. 6: 160-168

Khayyat L, Essawy A, Sorour J, Al Rawi M, 2014. Impact of Some Energy Drinks on the Structure and Function of the Kidney in Wistar Albino Rats. Life Sci J. 11(10): 11311138.

Luma QA, 2019 Histological and Physiological Studies on the Longterm Effect of Different Concentrations of Energy Drink (Tiger) on the Renal and Hepatic Systems of Young Mice. Baghdad Science Journal. 16(4):0816

Sacks FM, Svetkey LP, Vollmer WM, 2001. Effects On Blood Pressure of Reduced Dietary Sodium And The Dietary Approaches To Stop Hypertension (DASH) Diet. The New England Journal of Medicine. 344: 3-10.
Seifert S M, Schaechter J L, Hershorin E R, Lipshultz S E. 2011. Health Effects of Energy Drinks on Children, Adolescents, and Young Adults. American Academy of Pediatrics. 127: 511-528.

Supriyadi W, Widowati, Sekar R. 2011. Tingkat Kualitas Hidup Pasien Gagal Ginjal Kronik Terapi Hemodialisis. Jurnal Kesehatan Masyarakat. 2: 107-112.

Taiwo OI, and Adesokan AA, 2018. Toxicodynamic Effects of 'Red Bull' Energy Drink in A Randomised Controlled Study on Local Strains of Adult Rabbits. Journal of Biology and Life Science. 9(1): 46-64.

Ugwuja El, 2014. Biochemical Effects of Energy Drinks Alone or in Combination with Alcohol in Normal Albino Rats. Advanced Pharmaceutical Bulletin. 4(1): 6974.

Wael M, Deema MA, Mona H, Enas Z, 2017. Effects of chronic consumption of energy drinks on liver and kidney of experimental rats. Tropical Journal of Pharmaceutical Research. 16 (12): 2849-2856. 
Pengaruh Pemberian Minuman Energi terhadap Kadar Serum Kreatinin Rattus norvegicus Budi Santo, Dorta Simamora

Wiradji SM, 2003. Keeping up your stamina with energy drinks, The Jakarta Post,

(Online), (http://www.thejakartapost.com /news/2003/07/20/ keeping-yourstamina-energy-drinks.html. 